\title{
A 12-week healthy living programme piloted in community mental health - is it feasible and what is achievable?
}

\author{
Samantha Caldwell BPsySc ${ }^{a}$ and Amanda Wheeler BPharm BSc PhD PGDipPsychPharm \\ PGCertPubHealth ${ }^{b}$
}

\begin{abstract}
a Psychologist, Browns Plains Adult Mental Health Service, MetroSouth, Queensland Health, Brisbane, Australia b Professor Mental Health, Griffith Health Institute, Griffith University, Brisbane, Australia and Clinical Associate Professor, Faculty of Medical and Health Sciences, University of Auckland, Auckland, New Zealand
\end{abstract}

\begin{abstract}
The physical health outcomes of people with mental illness are significantly poorer compared to the normal population. The aims of this study were: (i) to assess the feasibility and outcomes of a 12-week healthy living programme piloted in a community adult mental health setting and (ii) to assess the lead author's research and evaluation competency as part of the conditions of the Psychology Supervised Practice Programme. Participants were referred to the programme to learn and develop healthy living skills, assist in weight management and enhance emotional wellbeing. The programme included weekly educational sessions followed by an activity related to the education for 3-4 hours, between June-September 2010 . The programme facilitators completed assessments with participants at Week 1 (baseline) and Week 12 (graduation) including demographic and physical health indicators (e.g., weight, BMI, blood pressure), psychological wellbeing and overall satisfaction with programme. Seventeen participants commenced the healthy living programme (HLP) pilot. There was an average weekly attendance of 11 people and 9 graduated at Week 12. No meaningful change in physical health or psychological wellbeing could be determined from the measurements at 12 weeks. However, the graduates rated the programme highly, particularly the social perspective and healthy eating skills. This feasibility assessment of the HLP pilot illustrates the difficulties inherent in real-world, service-based research, but also highlights the potential benefits for future replication of the HLP for enhancing both physical health and quality of life for people with a serious mental illness. We advance our study as an important contribution to the person-centered healthcare literature.
\end{abstract}

\section{Keywords}

Community mental health, evaluation, group programme, healthy living, person-centered healthcare, physical health

\section{Correspondence address}

Professor Amanda Wheeler, Griffith Health Institute, Griffith University, Brisbane, Queensland 4131, Australia.

E-mail: a.wheeler@griffith.edu.au

Accepted for publication: 29 July 2013

\section{Introduction}

People living with mental illness have poorer physical health outcomes and have a shortened life expectancy (about 10-15 years) compared to the normal population [14]. They are more likely to suffer from smoking related diseases, have poor diet, less likely to attend regular preventative health checks (e.g., cardiovascular disease [CVD]) and be less physically active [5-8]. Many of the physical health problems are preventable and treatable. In addition, many studies have shown that psychotropic medications, such as antipsychotics and mood stabilisers, are associated with weight gain, diabetes and metabolic syndrome [9-13].

The research paints a bleak picture for the health of individuals living with a mental illness and thus service interventions to target these physical health problems have been extensively studied [14-20]. In the United Kingdom, a 2-year programme was implemented to improve the overall health of individuals living with mental illness by providing physical health checks, education, weight management and physical activity groups [14]. The authors found that many of the risk factors for CVD could be identified and modified in this population, but only when health professionals focused on and targeted these issues through interventions. Richardson et al.'s [20] review of the literature also supported the need for healthy lifestyle interventions with people experiencing serious mental illness. They recommended that integrating healthy lifestyle programmes into community mental health settings was likely to increase adherence to lifestyle changes and new learning as interventions can be easily and more readily targeted during their routine appointments [20]. Similarly, Crompton et al. [21] suggested that high mortality rates of people with schizophrenia could be reduced if community mental health services focused on physical health monitoring and healthy lifestyle interventions. 
Table 1 Healthy Living Programme (HLP) Outline*

\begin{tabular}{|c|c|c|c|c|c|}
\hline Week & $\begin{array}{l}\text { Session } \\
\text { Topic }\end{array}$ & Session Activities & $\begin{array}{l}\text { Community } \\
\text { Outing }\end{array}$ & Homework Activity & Other Comments \\
\hline 1 & Introduction & $\begin{array}{c}\text { - Icebreakers } \\
\text { - Pre-programme } \\
\text { questionnaire } \\
\text { - Link between healthy } \\
\text { lifestyle \& mental/physical } \\
\text { wellbeing }\end{array}$ & - Ten pin bowling & $\begin{array}{l}\text { Write down one meal that you have } \\
\text { this week }\end{array}$ & \\
\hline 2 & $\begin{array}{c}\text { Food } \\
\text { knowledge }\end{array}$ & $\begin{array}{l}\text { - The } 5 \text { food groups } \\
\text { - Healthy plate activity }\end{array}$ & $\begin{array}{l}\text { - Relaxation } \\
\text { - Board Games } \\
\text { - Puzzles } \\
\text { - Art/Drawing }\end{array}$ & $\begin{array}{c}\text { Bring to the group a balanced meal } \\
\text { you had this week }\end{array}$ & $\begin{array}{l}\text { Video } \\
\text { Guest Speaker } \\
\text { (Dietician) }\end{array}$ \\
\hline 3 & Food options & $\begin{array}{l}\text { - Healthy snack choices } \\
\text { - Healthy take away options }\end{array}$ & $\begin{array}{l}\text { - Tennis } \\
\text { - Basketball } \\
\text { - Netball }\end{array}$ & $\begin{array}{l}\text { Tell us about the snacks you had } \\
\text { this week }\end{array}$ & Video \\
\hline 4 & $\begin{array}{l}\text { Food } \\
\text { planning }\end{array}$ & $\begin{array}{l}\text { - Shopping on a budget } \\
\text { - Food storage } \\
\text { - Food labels } \\
\text { - Creating a shopping list }\end{array}$ & $\begin{array}{l}\text { - Gym } \\
\text { - Swimming } \\
\text { - Cricket }\end{array}$ & $\begin{array}{c}\text { What do you normally get on a } \\
\text { shopping trip? }\end{array}$ & $\begin{array}{l}\text { Video } \\
\text { Guest Speaker } \\
\text { (Woolworths } \\
\text { Representative) }\end{array}$ \\
\hline 5 & $\begin{array}{l}\text { Applying } \\
\text { knowledge }\end{array}$ & $\begin{array}{c}\text { - Visit a supermarket } \\
\text { - Develop a theoretical } \\
\text { shopping list } \\
\text { - Decide on a meal for next } \\
\text { week (dessert, main, drinks) }\end{array}$ & $\begin{array}{l}\text {-Visit the } \\
\text { supermarket }\end{array}$ & $\begin{array}{l}\text { Think about a meal } \& \text { dessert we } \\
\text { could cook together }\end{array}$ & Video \\
\hline 6 & $\begin{array}{l}\text { Practical } \\
\text { cooking }\end{array}$ & $\begin{array}{l}\text { - Cook a meal } \\
\text { - Review past } 6 \text { weeks }\end{array}$ & - Cooking a meal & $\begin{array}{l}\text { List your favourite physical activities } \\
\text { to share with the group }\end{array}$ & $\begin{array}{l}\text { Video } \\
\text { Guest Speaker } \\
\text { (Catering Unit) }\end{array}$ \\
\hline 7 & $\begin{array}{l}\text { Exercise } \\
\text { (getting } \\
\text { started) }\end{array}$ & $\begin{array}{l}\text { - Healthy physical activities } \\
\text { - Incidental \& planned } \\
\text { exercise } \\
\text { - Endurance \& motivation } \\
\text { - Exercise schedules }\end{array}$ & $\begin{array}{c}\text { - Gym } \\
\text { - Dancing } \\
\text { - Bush walking }\end{array}$ & $\begin{array}{c}\text { What new things did you try this } \\
\text { week? }\end{array}$ & $\begin{array}{c}\text { Video } \\
\text { Guest Speaker } \\
\text { (Fitness Instructor) }\end{array}$ \\
\hline 8 & $\begin{array}{c}\text { Exercise } \\
\text { (keep going) }\end{array}$ & $\begin{array}{l}\text { - Review } \\
\text { - Activity plan }\end{array}$ & $\begin{array}{l}\text { - Light session at } \\
\text { local Gym }\end{array}$ & $\begin{array}{l}\text { What are some major things you'd } \\
\text { like to work on? }\end{array}$ & Guest Speaker \\
\hline 9 & $\begin{array}{l}\text { Motivation } \\
\text { (goal } \\
\text { planning) }\end{array}$ & $\begin{array}{l}\text { - Issues in my life } \\
\text { - Making a Plan }\end{array}$ & - Golf - driving range & $\begin{array}{c}\text { What do you do to care for } \\
\text { yourself? }\end{array}$ & $\begin{array}{l}\text { Video } \\
\text { Guest Speaker }\end{array}$ \\
\hline 10 & $\begin{array}{l}\text { Looking after } \\
\text { yourself }\end{array}$ & $\begin{array}{l}\text { - Coping with withdrawal } \\
\text { - Resources } \\
\text { - Self-care / management } \\
\text { - Medication }\end{array}$ & $\begin{array}{l}\text { - Local Community } \\
\text { Centre }\end{array}$ & $\begin{array}{c}\text { Count how many caffeinated drinks } \\
\text { you have in one day } \\
\text { Count how many cigarettes you } \\
\text { have in one day }\end{array}$ & $\begin{array}{l}\text { Video } \\
\text { Guest Speaker } \\
\text { (Dental } \\
\text { Technician) }\end{array}$ \\
\hline 11 & $\begin{array}{l}\text { Help with } \\
\text { caffeine, } \\
\text { alcohol and } \\
\text { drugs } \\
\text { Help to quit } \\
\text { smoking }\end{array}$ & $\begin{array}{l}\text { - About cannabis } \\
\text { - About caffeine } \\
\text { - About alcohol } \\
\text { - Resources to help with a } \\
\text { drug problem } \\
\text { - About smoking }\end{array}$ & $\begin{array}{c}\text { - Residual activity } \\
\text { e.g., frisbee in the } \\
\text { park }\end{array}$ & $\begin{array}{l}\text { Think about what you liked and } \\
\text { didn't like about the group }\end{array}$ & $\begin{array}{l}\text { Video } \\
\text { Guest Speaker } \\
\text { (Alcohol and } \\
\text { Drugs) }\end{array}$ \\
\hline 12 & Graduation & $\begin{array}{c}\text { - Quick review of last } 6 \text { weeks } \\
\text { - Post-programme } \\
\text { questionnaire } \\
\text { - BBQ in the park \& certificate } \\
\text { awarded }\end{array}$ & $\begin{array}{l}\text {-BBQ in the park / } \\
\text { beach }\end{array}$ & & \\
\hline
\end{tabular}

*=based on MindBodyLife ${ }^{\circledR}$ Programme www.mindbodylife.com.au.

Jones et al. reported on the impact of a 10-week lifestyle programme in Victoria, Australia, for people on antipsychotic medication which focused on education and development of skills for diet and exercise management [22]. They found a modest improvement across all measures (body weight, health status, plasma glucose and lipid profile) and suggested that a healthy lifestyle was achievable for individuals with mental illness.
Based on the outcomes of the Victorian programme, a community mental health service in Queensland, Australia, piloted a similar 12-week healthy living skills group in 2010 (Table 1). The healthy living programme (HLP) pilot was built on the group-based MindBodyLife ${ }^{\circledR}$ Programme developed by the pharmaceutical company Eli Lilly, which includes topics such as; healthy eating, exercise, selfesteem, meal planning, activity scheduling and motivation 
[23]. Mental health service staff, consumers and carers can access the resources free of charge at:

www.mindbodylife.com.au.

The HLP pilot aimed to improve the physical and emotional wellbeing of a group of participants with serious mental illness. This paper describes the assessment of feasibility and outcomes achieved with the HLP pilot as a contribution to the development of person-centered healthcare.

\section{Method}

This study formed a final part of the lead author's assessment for Research and Evaluation Competency within the Supervised Practice Program for Psychology. Participants were referred to the HLP by clinical teams in general adult mental health services across the Region. All participants were consumers of a government operated mental health service ${ }^{1}$ in Queensland, Australia, who volunteered to participate in the programme.

The HLP educational sessions were conducted in the conference rooms of a community health centre and the various learning-related activities were conducted in the local community (Table 1). Four health professionals from varying disciplines facilitated each session. The educational component included a PowerPoint presentation (developed by the facilitators) related to the weekly topic. All 4 facilitators arranged transport for participants to and from the HLP session and the learning-related activity. The facilitators also telephoned each participant one day prior to confirm numbers for the activity arranged. The educational session ran for approximately 1 - 1.5 hours with a 30-minute break and the related activity followed on for approximately 2 hours. Following each session, the facilitators documented the participants' progress in the clinical record.

Each participant was provided with a manual to work with during the weekly education sessions. The manual covered 11 modules with a range of health-related topics and activities in each module to assess knowledge acquired in a clear, easy to read format. Data collected as part of the evaluation included participant demographics, diagnosis, duration of time with mental illness, clinical indicators (weight, Body Mass Index (BMI), blood pressure, hipwaist ratio, plasma glucose and lipid profile), Mental Health Inventory (MHI) [24], measured at the start (Week $1=\mathrm{T} 1$ ) and completion (Week 12=T2) of the programme. A satisfaction survey (consisting of 10-items: 7-items were a 5-point Likert-scale and 3-items requested written feedback) was given to participants who attended the last HLP session (Week 12=T2). The facilitators prior to starting the first and last sessions collected evaluation data. Participant data from the 2 assessment points (Weeks 1 and 12) were compared to assess change over time. Ethical approval was obtained for this evaluation from the local

\footnotetext{
${ }^{1}$ Service provides community and inpatient mental healthcare to a catchment population of around 350,000 in a rapidly growing area of Queensland, Australia.
}

Health and Research Ethics Committee (NTX/09/150/EXP).

\section{Results}

Seventeen participants were referred and commenced the HLP pilot in June 2010. Table 2 outlines the demographic and clinical indicators for these 17 participants. Unfortunately, there was missing data due to a number of reasons: (i) a number of participants did not attend the first session and this was not collected at Week 2; (ii) hip and waist measurements were not reliably measured and (iii) pathology forms for investigations such as blood glucose and lipid profile were given to participants, but were not followed up by the facilitators. The participants were mostly male, with a mean age of 31 years, a diagnosis of schizophrenia, schizoaffective or bipolar disorder and had been in contact with mental health services for a mean of 3.2 years and more than two-thirds were current smokers.

\section{Table 2 HLP Cohort Description at Baseline and Graduation}

\begin{tabular}{|l|c|c|}
\hline & T1 & T2 \\
\hline Gender & $\mathbf{n ~ ( \% )}$ & $\mathbf{n}(\%)$ \\
Male & $14(82.4)$ & $8(88.9)$ \\
Female & $3(17.6)$ & $1(11.1)$ \\
\hline Age (years) & & \\
Mean & 31 & 30.8 \\
Median & 32 & 32 \\
\hline Diagnosis & $\mathbf{n ~ ( \% )}$ & $\mathbf{n ~ ( \% )}$ \\
Schizophrenia & $9(52.9)$ & $9(100)$ \\
Schizoaffective & $2(11.8)$ & - \\
Bipolar & $3(17.6)$ & - \\
Other & $3(17.6)$ & - \\
\hline Time with MHS & & \\
(years) & & 3.5 \\
Mean & 3.2 & 2.5 \\
Median & 2.5 & $\mathbf{n ~ ( \% )}$ \\
\hline Smoking status & $\mathbf{n ~ ( \% )}$ & $6(66.7)$ \\
Yes & $12(70.6)$ & $\mathbf{9}(33.3)$ \\
No & $5(29.4)$ & $\mathbf{1 7}$ \\
\hline TOTAL & & \\
\hline
\end{tabular}

HLP=Healthy living programme; T1=Week 1 of programme (baseline); T2=Week 12 of programme (graduation)

Programme attendance fluctuated on a weekly basis with an average of 11 participants per week (median=9; range $=8-13)$. Only 9 participants $(52.9 \%)$ graduated at Week 12 (Table 2): 8 men; all diagnosed with schizophrenia and had been involved with mental health services for a mean of 3.5 years (range $=0.5-8.5$ ). Results for physical health measures for the graduating cohort $(\mathrm{n}=9)$ are described in Table 3 at Weeks 1 (T1) and 12 (T2). At Week 1, 3 participants were within the normal/healthy BMI range (between 20-25 for young and middle-aged adults;

www.betterhealth.vic.gov.au/bhcv2/bhcsite.nsf/pages/bmi, 3 were overweight $(26-30)$ and 3 were obese $(>30)$. At Week 12 there was very little change from baseline. 
Table 3 HLP Graduation Cohort Physical Health Indicators

\begin{tabular}{|c|c|c|c|c|c|c|c|c|}
\hline \multirow[b]{2}{*}{ Participant } & \multicolumn{2}{|c|}{ Weight (kg) } & \multicolumn{2}{|c|}{ BMI } & \multicolumn{2}{|c|}{ Pulse } & \multicolumn{2}{|c|}{ Blood pressure } \\
\hline & T1 & T2 & T1 & T2 & T1 & T2 & T1 & T2 \\
\hline 1 & 90.5 & 88.8 & 28.9 & 28.3 & 118 & 96 & $142 / 102$ & $132 / 90$ \\
\hline 2 & 62.1 & 67.7 & 20.6 & 22.5 & 66 & 72 & $116 / 70$ & $133 / 75$ \\
\hline 3 & 94.6 & 94.8 & 31.2 & 31.3 & 96 & 69 & $138 / 80$ & $134 / 80$ \\
\hline 4 & 62.0 & 67.5 & 23.3 & 25.4 & 84 & 74 & $118 / 70$ & $124 / 74$ \\
\hline 5 & 73.3 & 70.3 & 21.0 & 20.1 & 106 & 98 & $109 / 83$ & $145 / 80$ \\
\hline 6 & 85.0 & 86.6 & 28.1 & 28.6 & 90 & 71 & $122 / 70$ & $124 / 68$ \\
\hline 7 & 129.0 & 128.4 & 35.0 & 34.8 & 104 & 105 & $142 / 81$ & $129 / 78$ \\
\hline 8 & 90.9 & 91.5 & 28.7 & 28.9 & - & 116 & $145 / 80$ & $140 / 87$ \\
\hline 9 & 116.0 & 114.9 & 32.1 & 31.8 & - & 98 & - & $151 / 93$ \\
\hline $\begin{array}{l}\text { Mean } \\
\text { Median }\end{array}$ & $\begin{array}{l}89.3 \\
90.5\end{array}$ & $\begin{array}{l}90.0 \\
88.8\end{array}$ & $\begin{array}{l}27.7 \\
28.7\end{array}$ & $\begin{array}{l}28.0 \\
28.6\end{array}$ & $\begin{array}{l}94.9 \\
96.0\end{array}$ & $\begin{array}{l}88.8 \\
96.0\end{array}$ & - & - \\
\hline
\end{tabular}

$\mathrm{HLP}=$ Healthy living programme; T1=Week 1 of programme (baseline); T2=Week 12 of programme (graduation)

Table 4: HLP Graduation Cohort Mental Health Inventory Scores

\begin{tabular}{|l|l|l|l|l|}
\hline & \multicolumn{2}{|c|}{ Psychological Wellbeing* } & \multicolumn{2}{c|}{ Psychological Distress\# } \\
\hline Participant & T1 & T2 & T1 & T2 \\
\hline $\mathbf{1}$ & 58 & 50 & 46 & 39 \\
\hline $\mathbf{2}$ & 80 & 73 & 37 & 33 \\
\hline $\mathbf{3}$ & 83 & 75 & 21 & 18 \\
\hline $\mathbf{4}$ & 66 & 58 & 31 & 34 \\
\hline $\mathbf{5}$ & 29 & 49 & 53 & 46 \\
\hline $\mathbf{6}$ & 53 & 68 & 21 & 20 \\
\hline $\mathbf{7}$ & 51 & 46 & 33 & 30 \\
\hline $\mathbf{8}$ & - & 62 & - & 39 \\
\hline $\mathbf{9}$ & - & 46 & - & 46 \\
\hline $\begin{array}{l}\text { Mean } \\
\text { Median }\end{array}$ & $\mathbf{6 0}$ & $\mathbf{5 8 . 6}$ & $\mathbf{3 4 . 6}$ & $\mathbf{3 3 . 9}$ \\
\hline
\end{tabular}

$\mathrm{HLP}=$ Health living programme; T1=Week 1 of programme (baseline); T2=Week 12 of programme (graduation)

*Raw score ranges from 14-84; high score indicates greater psychological wellbeing

\#Raw score ranges from 24-142; high score indicates greater psychological distress

Participants' blood pressure did not change markedly between Weeks 1 and 12; at baseline 3 participants had normal blood pressure $(<120 / 80 \quad \mathrm{mmHg}$; www.betterhealth.vic.gov.au/bhcv2/bhcarticles.nsf/pages/ Blood_pressure_explained?open), 2 were in the higher range of normal (between $120 / 80 \mathrm{mmHg}$ and 139/89 $\mathrm{mmHg}$ ) and 4 had mildly high blood pressure (between $140 / 90 \mathrm{mmHg}$ and $159 / 99 \mathrm{mmHg}$ ). At Week 12, 2 participants had reduced by 1 category and 2 had increased by 1,3 had no change and 1 increased by 2 categories.

Mental Health Inventory scores for psychological wellbeing and distress are shown in Table 4. Higher scores on the wellbeing scale indicate more positive mental health and less intensive/frequent symptoms (e.g., cheerfulness and enjoyment in life), while higher scores on the distress scale relate to negative mental health such as severity of more symptoms (e.g., anxiety and depression). There was very little change for the 9 graduates between Week 1 and 12.

The satisfaction question results conducted at completion are shown in Figure 1. Overall, the majority of participants rated each of the 7 Likert statements $(1=$ low and $5=$ high) with a 3 or higher. In the 3 open-comment questions, participants reported that the social aspects of the group-based programme - the activities and meeting other participants - were the things they liked the most about the HLP. Overall, the main suggestion for improvement was to increase time spent on the learningrelated activities. Most participants also provided written feedback that they learnt to eat healthier and to be more conscious of their diet.

\section{Disc ussion}

In this study, only half of the 17 participants $(52.9 \%)$ graduated from the 12-week HLP. No meaningful change in participants' physical health or psychological wellbeing could be determined from the measurements at 12 weeks. However, those that did graduate rated the programme highly, particularly the social perspective and healthy 
Figure 1 Participant Satisfaction with Healthy Living Programme*

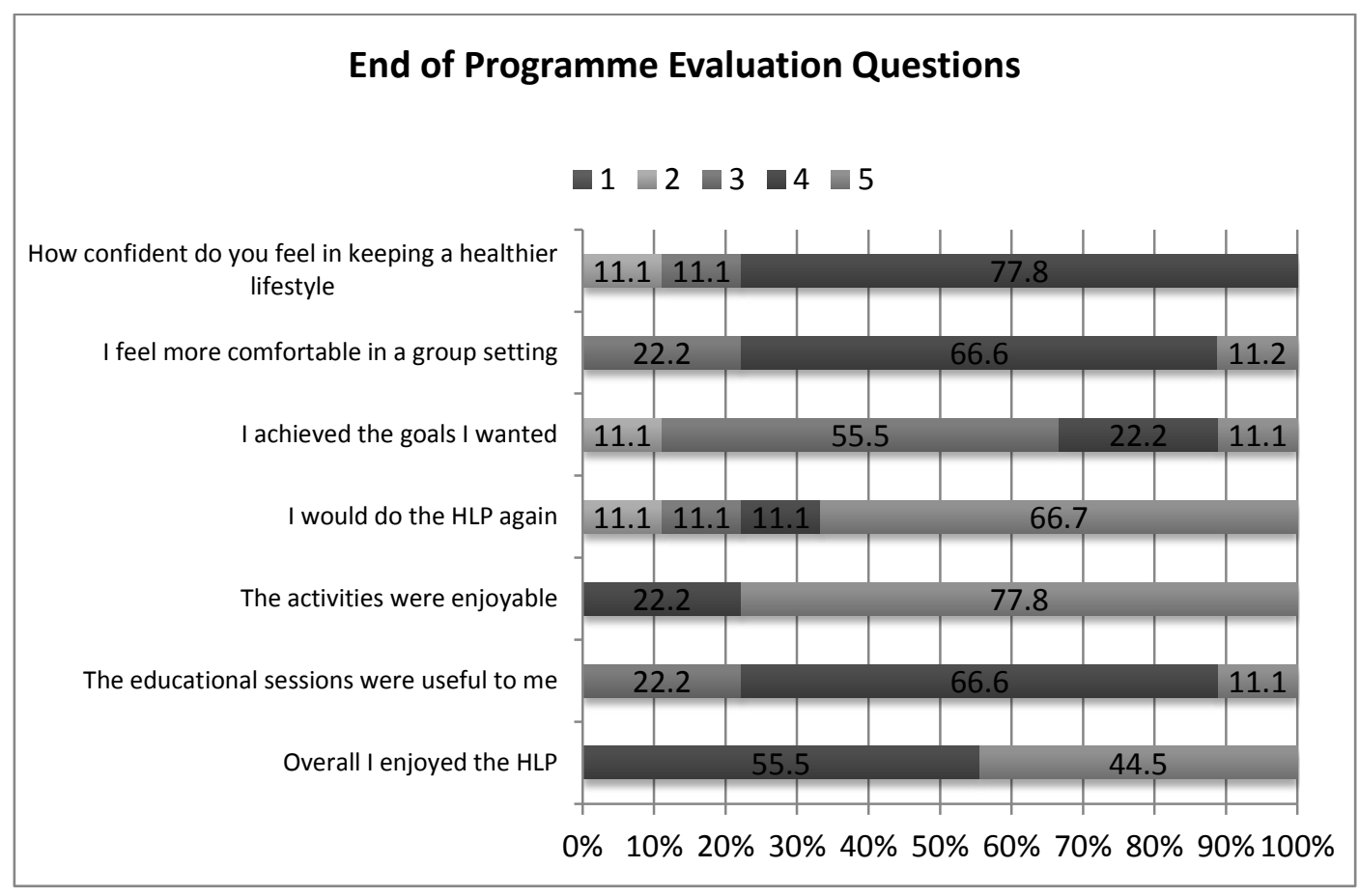

*Likert scales rating: 1=low and 5=high HLP=Healthy Living Programme

eating skills.

The earlier study by Jones et al. [22] did not find any statistically significant changes with a 10-week programme, but most indicators showed a modest improvement. Our study was not able to detect similar changes, but the small sample size of participants with data for comparison may have influenced our findings. Importantly, it is mindful to consider that in a short-term programme consisting of 12-weekly sessions of 3-4 hours, it is unlikely that significant weight loss and corresponding BMI is achievable. For the future it may be beneficial to extend the length of the programme to allow for consolidation of new skills and assist in longer-term behaviour change. Offering participants the opportunity to repeat the programme may also be beneficial especially when regular weekly attendance for the entire 12 weeks may be difficult to sustain.

Additionally, the measures used in the evaluation were unable to assess learning, motivation or behaviour change explicitly. It may be that in this short period the participants learn practical strategies to improve their physical and emotional health and this would be a positive outcome. In any future replication of the programme it would be recommended that measures be used to assess motivation level as criteria for eligibility and investigate learning and new behaviour change more formally.

This pilot evaluation should be viewed in the context of its limitations. Firstly, the small sample size of participants with comparison data from Weeks 1 and 12 and the amount of missing data for the baseline measures made it very difficult to evaluate the effectiveness of the programme. The HLP had a relatively high weekly attendance rate. However, only 9 participants had data collected for comparison at both commencement and graduation. Retention in a programme requiring 3-4 hours commitment weekly over 12 consecutive weeks is a challenge for participants who may have a number of other competing commitments including employment, study, or other carer responsibilities. Larger participant samples and combining data from multiple programmes run in several locations may reduce this problem. The HLP and data collection for the evaluation were carried out in a realworld mental health practice setting by health professionals as part of their regular activities. There were no additional personnel resources to deliver the programme or manage the data collection as would be expected for a clinical trial. While this provides valuable feasibility and effectiveness information about the programme, in the future a small amount of dedicated research assistant time to conduct data collection at the commencement and completion sessions (and to follow-up those who may miss one of these visits) would be a valuable investment. It is also concerning to find such a high degree of missing baseline and follow-up physical health assessment in routine practice despite significant attention being drawn to the poorer physical health of people with a mental illness and the national and international calls to address this. Lastly, longitudinal assessment of knowledge and behaviour change should be included in future applications of the HLP, such as assessment 4-8 weeks after the graduation session.

Despite these limitations, there was a high average attendance throughout the HLP. Almost two-thirds of the 
referred participants attended weekly regardless of only a small sample participating in the evaluation data collection. The facilitators arranged transport to and from the weekly education and activity sessions for all participants and telephoned one day prior to remind participants. This is likely to have influenced attendance.

A secondary outcome of this evaluation was the opportunity it provided for the lead author's professional development particularly in research and evaluation competency for Psychologist Registration. This evaluation provided practical experience of conducting research in a real world clinical work setting and applying theoretical research principles where ideal experimental conditions cannot always be met and adaptability is required.

\section{Conclusion}

In conclusion, the evaluation of the HLP pilot in a public community mental health setting illustrates the difficulties inherent in real-world, service-based evaluation, but also highlights the potential benefits for future replication of the HLP for enhancing both physical health and quality of life for people with a serious mental illness. Additionally, the evaluation also allowed the lead author to complete the research and evaluation competency of the Psychology Supervised Practice Program. The current article, despite some methodological limitations, is advanced as an important contribution to the evolving person-centered healthcare literature.

\section{Acknowledgements and Conflicts of Interest}

This evaluation was undertaken as part of the first author's requirements for competency assessment under the conditional registration programme for Psychologists practising in Australia. Eli Lilly Australia Pty Ltd supported the MindBodyLife ${ }^{\circledR}$ programme and resources but they had no role in the evaluation or preparation of this manuscript. The authors declare no conflicts on interest.

\section{References}

[1] Carney, C.P. \& Jones, L.E. (2006). Medical comorbidity in women and men with bipolar disorders: a population-based controlled study. Psychosomatic Medicine 68 (5) 684-691.

[2] Newman, S.C. \& Bland, R.C. (1991). Mortality in a cohort of patients with schizophrenia: a record linkage study. Canadian Journal of Psychiatry - Revue Canadienne de Psychiatrie 36 (4),239-245.

[3] Capasso, R.M., Lineberry, T.W., Bostwick, J.M., Decker, P.A. \& St Sauver, J. (2008). Mortality in schizophrenia and schizoaffective disorder: an Olmsted County, Minnesota cohort: 1950-2005. Schizophrenia Research 98 (1-3) 287-294.
[4] Joukamaa, M., Heliovaara, M., Knekt, P., Aromaa, A., Raitasalo, R. \& Lehtinen, V. (2001). Mental disorders and cause-specific mortality. British Journal of Psychiatry 179, 498-502.

[5] de Lusignan, S., Chan, T., Cohen, A., Thana, L., Dhoul, N., Hague, N. \& van Vlymen, J. (2005). Health education and prevention for people with severe mental illness: a cross-sectional study of general practice computer records. Primary Care Mental Health 3 (3) 221-233.

[6] Filik, R., Sipos, A., Kehoe, P.G., Burns, T., Cooper, S.J., Stevens, H., Laugharne, R., Young, G., Perrington, S., McKendrick, J., Stephenson, D. \& Harrison, G. (2006). The cardiovascular and respiratory health of people with schizophrenia. Acta Psychiatrica Scandinavica 113 (4) 298-305.

[7] Birkenaes, A.B., Opjordsmoen, S., Brunborg, C., Engh, J.A., Jonsdottir, H., Ringen, P.A., Simonsen, C., Vaskinn, A., Birkeland, K.I., Friis, S., Sundet, K. \& Andreassen, O.A. (2007). The level of cardiovascular risk factors in bipolar disorder equals that of schizophrenia: a comparative study. Journal of Clinical Psychiatry 68 (6) 917-923.

[8] Voruganti, L.P., Punthakee, Z., Van Lieshout, R.J., MacCrimmon, D., Parker, G., Awad, A.G. \& Gerstein, H.C. (2007). Dysglycemia in a community sample of people treated for schizophrenia: the Diabetes in Schizophrenia in Central-South Ontario (DiSCO) study. Schizophrenia Research 96 (1-3) 215-222.

[9] Kilbourne, A.M., Brar, J.S., Drayer, R.A., Xu, X. \& Post, E.P. (2007). Cardiovascular disease and metabolic risk factors in male patients with schizophrenia, schizoaffective disorder, and bipolar disorder. Psychosomatics 48 (5) 412-417.

[10] Citrome, L., Jaffe, A., Levine, J., Allingham, B. \& Robinson, J. (2004). Relationship between antipsychotic medication treatment and new cases of diabetes among psychiatric inpatients. Psychiatric Services 55 (9) 10061013.

[11] Newcomer, J.W. (2005). Second-generation (atypical) antipsychotics and metabolic effects: a comprehensive literature review. CNS Drugs 19 (Supplement 1) 1-93.

[12] Kalarchian, M.A., Marcus, M.D., Levine, M.D., Haas, G.L., Greeno, C.G., Weissfeld, L.A. \& Qin, L. (2005). Behavioral treatment of obesity in patients taking antipsychotic medications. Journal of Clinical Psychiatry 66 (8) 1058-1063.

[13] Mauri, M., Castrogiovanni, S., Simoncini, M., Iovieno, N., Miniati, M., Rossi, A., Dell'Agnello, G., Fagiolini, A., Donda, P. \& Cassano, G.B. (2006). Effects of an educational intervention on weight gain in patients treated with antipsychotics. Journal of Clinical Psychopharmacology 26 (5) 462-466.

[14] Smith, S., Yeomans, D., Bushe, C.J.P., Eriksson, C., Harrison, T., Holmes, R., Mynors-Wallis, L., Oatway, H. \& Sullivan, G. (2007) A well-being programme in severe mental illness. Baseline findings in a UK cohort. International Journal of Clinical Practice 61 (12) 19711978.

[15] Barnes, T.R.E., Paton, C., Hancock, E., Cavanagh, M.R., Taylor, D. \& Lelliott, P. (2008). Screening for the metabolic syndrome in community psychiatric patients 
prescribed antipsychotics: A quality improvement programme. Acta Psychiatrica Scandinavica 118 (1) 2633.

[16] Dunbar, L., Wheeler, A., Harrison, J., Brandt, T., Pulford, J., Condell, W. \& Stoepker, J. (2010). Implementing metabolic risk assessment in a secondary care mental health service. Australasian Psychiatry 18 (4) 318-321.

[17] Dunbar, L., Brandt, T., Wheeler, A. \& Harrison, J. (2010). Barriers and solutions to implementing metabolic risk assessment in a secondary mental health service. Australasian Psychiatry 18 (4) 322-325.

[18] Baker, A., Richmond, R., Castle, D., Kulkarni, J., Kay-Lambkin, F., Sakrouge, R., Filia, S. \& Lewin, T.J. (2009). Coronary heart disease risk reduction intervention among overweight smokers with a psychotic disorder: Pilot trial. Australian and New Zealand Journal of Psychiatry 43, 129-135.

[19] Baker, A., Kay-Lambkin, F.J., Richmond, R., Filia, S., Castle, D., Williams, J.E. \& Lewin, T.J. (2011). Study protocol: a randomised controlled trial investigating the effect of a health lifestyle intervention for people with severe mental disorders. BMC Public Health 11, 10.

[20] Richardson, C.R., Faulkner, G., McDevitt, J., Skrinar, G.S., Hutchinson, D.S. \& Piette, J.D. (2005). Integrating physical activity into mental health services for persons with serious mental illness. Psychiatric Services 56 (3) 324-331.

[21] Crompton, D., Groves, A. \& McGrath, J. (2010). What can we do to reduce the burden of avoidable deaths in those with serious mental illness? Epidemiologia $e$ Psichiatria Sociale 19 (1) 4-7.

[22] Jones, A., Benson, A., Berk, M. \& Dodd, S. (2009). Mind and Body': a lifestyle programme for people on antipsychotic medication. Journal of Evaluation in Clinical Practice 15 (2) 276-280.

[23] Eli Lilly Australia Pty. Ltd. (2008). Mind Body Life: Your workbook. [cited 201128 September]; Available from: www.mindbodylife.com.au.

[24] Coombs, T. (2005). Australian Mental Health Outcomes and Classification Network: Mental Health Inventory Training Manual.[cited 201121 May]; Available from: http://amhocn.org/../MHI_Manual.pdf 